\title{
DIRECT APPLICATIONS OF PRODUCT LIFE CYCLE ASSESSMENT IN CIRCULAR ECONOMY
}

\author{
Jolanta BARAN \\ Politechnika Śląska, Wydział Organizacji i Zarządzania, Katedra Ekonomii i Informatyki; \\ jolanta.baran@polsl.pl, ORCID: 0000-0003-3144-8257
}

\begin{abstract}
Purpose: The purpose of the article is to analyse the possibilities of using life cycle assessment in circular economy. Direct applications of LCA are being considered, including product development and improvement, strategic planning, public policy making and marketing.
\end{abstract}

Design/methodology/approach: Literature research of the subject was carried out.

Findings: The possibilities and challenges of applying LCA were indicated. This methodology, in accordance with the provisions of the new circular economy action plan, is becoming increasingly important.

Practical implications: A comparison of two or more products in terms of environmental impacts in the life cycle, desired by both companies and customers (in both business-to-business and business-to-client relations), is also difficult to do at the same time. First of all, it requires the use of uniform analytical assumptions. The article contains tips on how to solve this problem. Particular hopes can be associated with the implementation of the environmental footprint being developed by the European Commission.

Social implications: The LCA can make a valuable contribution to public policy formulation because it allows policymakers to take into account potential unintended environmental consequences that otherwise cannot be predicted.

Originality/value: An analysis of applying LCA was made in relation to the new circular economy action plan (issued in March 2020). Great emphasis was placed on the quantitative approach to the results obtained, which determines the relevance of the article.

Keywords: life cycle assessment, circular economy, environmental footprint, ecodesign, environmental management.

Category of the paper: General review.

\section{Introduction}

Life cycle assessment (LCA) is an environmental management technique based on ISO 14040/44 standards (ISO 14040, 2006; ISO 14044, 2006). It is used to assess the environmental impact of products, services and business models in the context of the 
environmental life cycle - from extraction of raw materials through production, distribution, to utility and disposal of waste.

Applying LCA in CE enables manufacturers to measure environmental performance, formulate new business strategies, and ensure environmental sustainability by eco-designing new products. It is also a tool that can bring added value in actions taken by public authorities and concrete benefits for consumers.

LCA is a method widely discussed in the scientific literature. It has found application in a huge number of case studies and industry studies. More and more enterprises are analysing the product life cycle, including primarily the carbon footprint, due to the widespread use of business applications of these measures. At the same time, it is worth noting the large space of LCA applications that is waiting to discover. It is worth noting that with the new Circular Economy Action Plan, the demand for the use of precise analytical tools, primarily LCA, increases. ISO 14040:2006 defines 4 areas of direct LCA applications - product development and improvement, strategic planning, public policy making and marketing. This article considers them in relation to the assumptions of circular economy and the new Circular Economy Action Plan, issued in March 2020.

\section{A general outline of the life cycle assessment methodology and its application}

Life cycle assessment is one of environmental management techniques that addresses the environmental aspects and potential environmental impacts (e.g. use of resources and environmental consequences of releases) throughout a product's life cycle from raw material acquisition through production, use, end-of-life treatment, recycling and final disposal (i.e. cradle-to-grave) (ISO 14040, 2006).

There are four LCA phases (ISO 14044, 2006):

- the goal and scope definition,

- the inventory analysis,

- the impact assessment, and

- the interpretation.

Each of these phases consists of a series of steps and decisions made by analysts and decision makers and is implemented in an iterative model.

In the first phase is determined, among others, a functional unit, i.e. the product reference unit, for which data is collected for unit processes throughout the entire life cycle that make up the product system. 
The data collection phase has a fundamental impact on the quality of the analysis because the uncertainty of the final result depends on their correctness and verifiability. In this respect, it is important to ensure a uniform approach to the modelled processes, i.e. data collection, recording and storage procedures.

The collected data is subjected to a life cycle impact assessment (LCIA), i.e. an assessment of the size and significance of the potential environmental impacts of the product system over the entire life cycle. To this end, specialised programmes (e.g. SimaPro, GaBi, Umberto, OpenLCA) are used together with LCIA methods and databases (e.g. ecoinvent), thanks to which the potential impact on the environment can be determined in relation to scientifically developed environmental mechanisms. The third phase consists of mandatory elements, including characterisation, and optional elements such as normalisation and weighting.

As a result of characterisation, we obtain the LCIA category indicator values for various impact categories, defined as the LCIA profile. Depending on the scope of the impact category considered, as well as the geographical scope, different LCIA methods are available. In the context of the circular economy, which is being implemented at European Union level, it is worth mentioning the impact categories defined under the environmental footprint (EF) (Table 1). Environmental footprint is a life cycle assessment (LCA) based method to quantify the environmental impacts of products (goods or services) (Zampori, 2019), developed by the European Commission. In a utilitarian sense, the environmental footprint is LCA, which responds to the need to compare the environmental impact of life-cycle products with the same functions, produced by different manufacturers. As part of the environmental footprint, homogeneous product groups are developing analysis rules (so-called Category Rules), which limits the subjectivity of decisions taken by LCA contractors for these products (European Platform on Life Cycle Assessment).

Due to the fact that the characterisation results may be less readable and, above all, it can not be determined which category of impact is more significant for a specific product (due to different units), optional LCIA elements are used, i.e. normalisation and weighting.

Normalisation involves calculating the category indicator relative to reference information (e.g. the potential environmental impact of one European citizen in 1 year). The results of normalisation are dimensionless, you can compare different categories of influence with respect to the relative importance of the indicator value.

Weighting is the process of transforming the indicator value in relation to the preferences of the examined group of experts or organisations. Specific impact categories are assigned weighting factors determined in the tests based on the value choices. It should be noted that weighting is not scientifically based, but may be useful in a better understanding and presentation of LCA results. 
Table 1.

EF impact categories with respective impact category indicators and characterization models

\begin{tabular}{|c|c|c|c|c|}
\hline No. & $\begin{array}{c}\text { EF Impact } \\
\text { category }\end{array}$ & $\begin{array}{l}\text { Impact category } \\
\text { Indicator }\end{array}$ & Unit & Characterization model \\
\hline 1 & $\begin{array}{l}\text { Climate change, } \\
\text { total }\end{array}$ & $\begin{array}{l}\text { Radiative forcing as global } \\
\text { warming potential } \\
\text { (GWP100) }\end{array}$ & $\mathrm{kg} \mathrm{CO}_{2}$ eq & $\begin{array}{l}\text { Baseline model of } 100 \text { years } \\
\text { of the IPCC (based on IPCC } \\
2013 \text { ) }\end{array}$ \\
\hline 2 & Ozone depletion & $\begin{array}{l}\text { Ozone Depletion Potential } \\
\text { (ODP) }\end{array}$ & kg CFC-11 eq & $\begin{array}{l}\text { Steady-state ODPs as in } \\
\text { (WMO } 2014+\text { integrations) }\end{array}$ \\
\hline 3 & $\begin{array}{l}\text { Human toxicity, } \\
\text { cancer }\end{array}$ & $\begin{array}{l}\text { Comparative Toxic Unit } \\
\text { for humans (CTUh) }\end{array}$ & CTUh & $\begin{array}{l}\text { USEtox model } 2.1 \text { (Fankte et } \\
\text { al, 2017) }\end{array}$ \\
\hline 4 & $\begin{array}{l}\text { Human toxicity, } \\
\text { non-cancer }\end{array}$ & $\begin{array}{l}\text { Comparative Toxic Unit } \\
\text { for humans (CTUh) }\end{array}$ & CTUh & $\begin{array}{l}\text { USEtox model } 2.1 \text { (Fankte et } \\
\text { al, 2017) }\end{array}$ \\
\hline 5 & $\begin{array}{l}\text { Particulate } \\
\text { matter }\end{array}$ & Impact on human health & disease incidence & $\begin{array}{l}\text { PM method recommended by } \\
\text { UNEP (UNEP 2016) }\end{array}$ \\
\hline 6 & $\begin{array}{l}\text { Ionising } \\
\text { radiation, human } \\
\text { health }\end{array}$ & $\begin{array}{l}\text { Human exposure efficiency } \\
\text { relative to } U^{235}\end{array}$ & $\mathrm{kBq} \mathrm{U}^{235} \mathrm{eq}$ & $\begin{array}{l}\text { Human health effect model as } \\
\text { developed by Dreicer et al. } \\
1995 \text { (Frischknecht et al, } \\
\text { 2000) }\end{array}$ \\
\hline 7 & $\begin{array}{l}\text { Photochemical } \\
\text { ozone formation, } \\
\text { human health }\end{array}$ & $\begin{array}{l}\text { Tropospheric ozone } \\
\text { concentration increase }\end{array}$ & kg NMVOC eq & $\begin{array}{l}\text { LOTOSEUROS model (Van } \\
\text { Zelm et al, 2008) as } \\
\text { implemented in ReCiPe } 2008\end{array}$ \\
\hline 8 & Acidification & $\begin{array}{l}\text { Accumulated Exceedance } \\
\text { (AE) }\end{array}$ & $\mathrm{mol} \mathrm{H}+\mathrm{eq}$ & $\begin{array}{l}\text { Accumulated Exceedance } \\
\text { (Seppälä et al. 2006, Posch et } \\
\text { al, 2008) }\end{array}$ \\
\hline 9 & $\begin{array}{l}\text { Eutrophication, } \\
\text { terrestrial }\end{array}$ & $\begin{array}{l}\text { Accumulated Exceedance } \\
\text { (AE) }\end{array}$ & mol $\mathrm{N}$ eq & $\begin{array}{l}\text { Accumulated Exceedance } \\
\text { (Seppälä et al. 2006, Posch et } \\
\text { al, 2008) }\end{array}$ \\
\hline 10 & $\begin{array}{l}\text { Eutrophication, } \\
\text { freshwater }\end{array}$ & $\begin{array}{l}\text { Fraction of nutrients } \\
\text { reaching freshwater end } \\
\text { compartment }(\mathrm{P})\end{array}$ & $\mathrm{kg} \mathrm{P}$ eq & $\begin{array}{l}\text { EUTREND model (Struijs et } \\
\text { al, 2009) as implemented in } \\
\text { ReCiPe }\end{array}$ \\
\hline 11 & $\begin{array}{l}\text { Eutrophication, } \\
\text { marine }\end{array}$ & $\begin{array}{l}\text { Fraction of nutrients } \\
\text { reaching marine end } \\
\text { compartment }(\mathrm{N})\end{array}$ & $\mathrm{kg} \mathrm{N} \mathrm{eq}$ & $\begin{array}{l}\text { EUTREND model (Struijs et } \\
\text { al, 2009) as implemented in } \\
\text { ReCiPe }\end{array}$ \\
\hline 12 & $\begin{array}{l}\text { Ecotoxicity, } \\
\text { freshwater }\end{array}$ & $\begin{array}{l}\text { Comparative Toxic Unit } \\
\text { for ecosystems (CTUe) }\end{array}$ & CTUe & $\begin{array}{l}\text { USEtox model } 2.1 \text { (Fankte et } \\
\text { al, 2017) }\end{array}$ \\
\hline 13 & Land use & $\begin{array}{ll}- & \text { Soil quality index } \\
- & \text { Biotic production } \\
- & \text { Erosion resistance } \\
- & \text { Mechanical filtration } \\
- & \text { Groundwater } \\
& \text { replenishment }\end{array}$ & $\begin{array}{l}- \text { dimensionless } \\
\text { (pt) } \\
-\mathrm{kg} \text { biotic } \\
\text { production } \\
-\mathrm{kg} \text { soil } \\
-\mathrm{m}^{3} \text { water } \\
-\mathrm{m}^{3} \text { groundwater }\end{array}$ & $\begin{array}{l}\text { Soil quality index based on } \\
\text { LANCA (Beck et al. } 2010 \\
\text { and Bos et al. 2016) }\end{array}$ \\
\hline 14 & Water use & $\begin{array}{l}\text { User deprivation potential } \\
\text { (deprivation-weighted } \\
\text { water consumption) }\end{array}$ & $\mathrm{m}^{3}$ world eq & $\begin{array}{l}\text { Available WAter REmaining } \\
\text { (AWARE) as recommended } \\
\text { by UNEP, } 2016\end{array}$ \\
\hline 15 & $\begin{array}{l}\text { Resource use, } \\
\text { minerals and } \\
\text { metals }\end{array}$ & $\begin{array}{l}\text { Abiotic resource depletion } \\
\text { (ADP ultimate reserves) }\end{array}$ & $\mathrm{kg} \mathrm{Sb}$ eq & $\begin{array}{l}\text { CML } 2002 \text { (Guinée et al., } \\
\text { 2002) and van Oers et al. } \\
2002 \text {. }\end{array}$ \\
\hline 16 & $\begin{array}{l}\text { Resource use, } \\
\text { fossils }\end{array}$ & $\begin{array}{l}\text { Abiotic resource depletion } \\
\text { - fossil fuels (ADP-fossil) }\end{array}$ & MJ & $\begin{array}{l}\text { CML } 2002 \text { (Guinée et al., } \\
2002) \text { and van Oers et al. } \\
2,002\end{array}$ \\
\hline
\end{tabular}

Source: Zampori, L. and Pant, R., Suggestions for updating the Product Environmental Footprint (PEF) method, EUR 29682 EN, Publications Office of the European Union, Luxembourg, 2019, ISBN 97892-76- 00654-1, doi:10.2760/424613, JRC115959 p. 35-37. 
ISO 14040 lists four main direct applications of LCA - product development and improvement, strategic planning, public policy making, marketing (ISO 14040, 2006).

Product development and improvement is mainly the area of eco-design, i.e. including environmental aspects in the design and development of products. ISO/TR 14062 provides recommendations in this regard. It is therefore a useful tool in developing eco-innovation (Olkiewicz et al., 2019).

LCA in the area of strategic planning can be used as part of assessing the environmental impact of strategic scenarios (Rebitzer, and Buxmann, 2005; Poeschl et al., 2012).

In the field of public policy making, LCA can provide quantitative information on the basis of which decisions regarding specific solutions are made. (Seidel, 2016).

In turn, a life cycle marketing strategy is becoming a way for companies to increase the efficiency of their efforts to develop new products while managing environmental impact (Lockrey, 2015).

\section{Circular economy - new Action Plan}

The circular economy is an economic concept in which raw materials, materials and products should remain in circulation as long as possible, while waste generation should be minimised as much as possible. This idea takes into account all stages of the product's life cycle, from the design phase, through the production, distribution, consumption, collection of postconsumer waste, to its final disposal. This means moving away from a linear economy based on the principle of 'extract, process, use and discard', in which waste is often treated as the last stage of the life cycle. In a circular economy, it is important that waste - if it is generated is treated as secondary raw materials. All those activities preceding waste generation are to serve this purpose. At the same time, the circular economy approach, implemented e.g. in relation to product design or production processes, aims to increase the innovation of European entrepreneurs and raise their competitiveness in relation to entities from other parts of the world.

In December 2015, the European Commission adopted the EU Circular Economy Action Plan to boost employment, growth and investment, and develop a carbon neutral, resourceefficient and competitive economy. On 4 March 2019, the European Commission Report on the implementation of the Circular Economy Action Plan (COM (2019) 190 final) was presented. It states that the circular economy is now an irreversible global trend on a large scale. However, much effort is still needed to intensify EU and global action, fully close the loop and take advantage of the competitive advantage that the circular economy provides for EU enterprises. In this context, a further challenge is for the circular economy to be at the heart of the EU's industrial strategy, which will enable a closed loop in new areas and sectors. The product life 
cycle assessment should become the norm and eco-design rules should be extended as much as possible (COM (2019) 190 final). With this message, a new Circular Economy Action Plan was developed (COM/2020/98 final). It sets out a sustainable product policy framework covering the design of sustainable products, empowering consumers and public buyers, and a closed loop in production processes. Key product value chains have also been identified for electronics and ICT, batteries, accumulators and vehicles, packaging, plastics, textiles, construction and buildings, as well as for food, water and nutrients. Actions are also proposed to reduce the amount of waste, adapt the closed loop to the needs of people, regions and cities, and take into account the global context of the implemented solutions (COM/2020/98 final).

The rest of the article analyses the possibility of using LCA in these areas in relation to its direct applications according to ISO 14040.

\section{Analysis of LCA applications in circular economy}

\subsection{Product development and improvement}

Decisions made at the design stage are even responsible for up to $80 \%$ of the natural environment's impact of products throughout the entire life cycle. However, the European Commission notes that manufacturers do not have sufficient incentives to implement eco-design principles. There is a lack of comprehensive solutions in this area, which is why the EC plans to propose legislative initiative on sustainable product policy. The basis for this initiative will be the extension of the Ecodesign Directive (Directive 2009/125/EC) beyond energy-related products, so that the eco-design framework applies to the widest range of products that would therefore meet the criteria of a closed loop (COM/2020/98 final).

The proposed actions will be based, among others on the product footprint approach. They will therefore be consistent with the LCA analytical approach developed for specific product groups.

Currently Product Environmental Footprint Category Rules (PEFCR) has been developed for the following products: beer, dairy, decorative paints, household liquid laundry detergents, hot and cold water supply pipe systems, intermediate paper product, feed for food producing animals, IT equipment, leather, metal sheets, packed water, pasta, pet food, photovoltaic electricity production, rechargeable batteries, T-shirt, thermal insulation, Uninterrupted Power Supply, wine (Results and deliverables of the Environmental Footprint pilot phase). The PEFCR developed for these products means that they can consider improving the environmental profile for all life cycle stages (Baran J., 2019). 
The above mentioned Ecodesign Directive covers the following product groups (Directive 2009/125/EC): computers and servers, solid fuel boilers, hot water boilers fired with liquid or gas, refrigerators and refrigerated cabinets, refrigerating appliances with direct sales function (from 01/03/2021), local space heaters, vacuum cleaners, space heaters and water heaters, lighting (from 1/09/2021 light sources and separate control gears), ovens, hobs and range hoods, pumps, washing machines, products for air heating and cooling, set-top boxes, electric motors, welding equipment, tumble driers, televisions, transformers, standby and off mode, fans and air conditioners as well as ventilation systems, power supplies, dishwashers. These products must be designed taking into account the principles of improving the environmental profile at individual stages of the life cycle.

The above product groups are characterised by the foundations laid for their use of LCA for comparative purposes. It is most desirable to apply LCA in the earliest stages of product design. This is associated with the so-called eco-design paradox, according to which the possibility of improving a product in terms of environmental impact decreases with the course of the eco-design process. Thus, the later the environmental aspects are undertaken, the less opportunities there are for significant changes to the environmental profile (Bhander et al., 2003; Baran J., 2017). This is due to the fact that significant decisions regarding e.g. the shape and composition of the product (parameters relevant from the point of view of the environmental profile) are taken in the earliest design stages (Poudelet et al., 2012; ISO/TR 14062, 2002)

The usefulness of LCA as an analytical tool, the use of which allows obtaining quantitative information on the impact of the product life cycle on the environment can be considered at individual stages of eco-design, i.e. within (ISO/TR 14062, 2002):

- planning,

- conceptual design,

- detailed design,

- prototype testing and assessment,

- production and placing on the market,

- product review related to feedback.

Figure 1 presents a general model for incorporating environmental aspects into the product design and development process with guidance on possible actions related to the integration of environmental aspects and LCA at individual stages of eco-design. It should be noted that, in fact, the design process is carried out in various ways for different products and organisations (Baran J., 2016). 


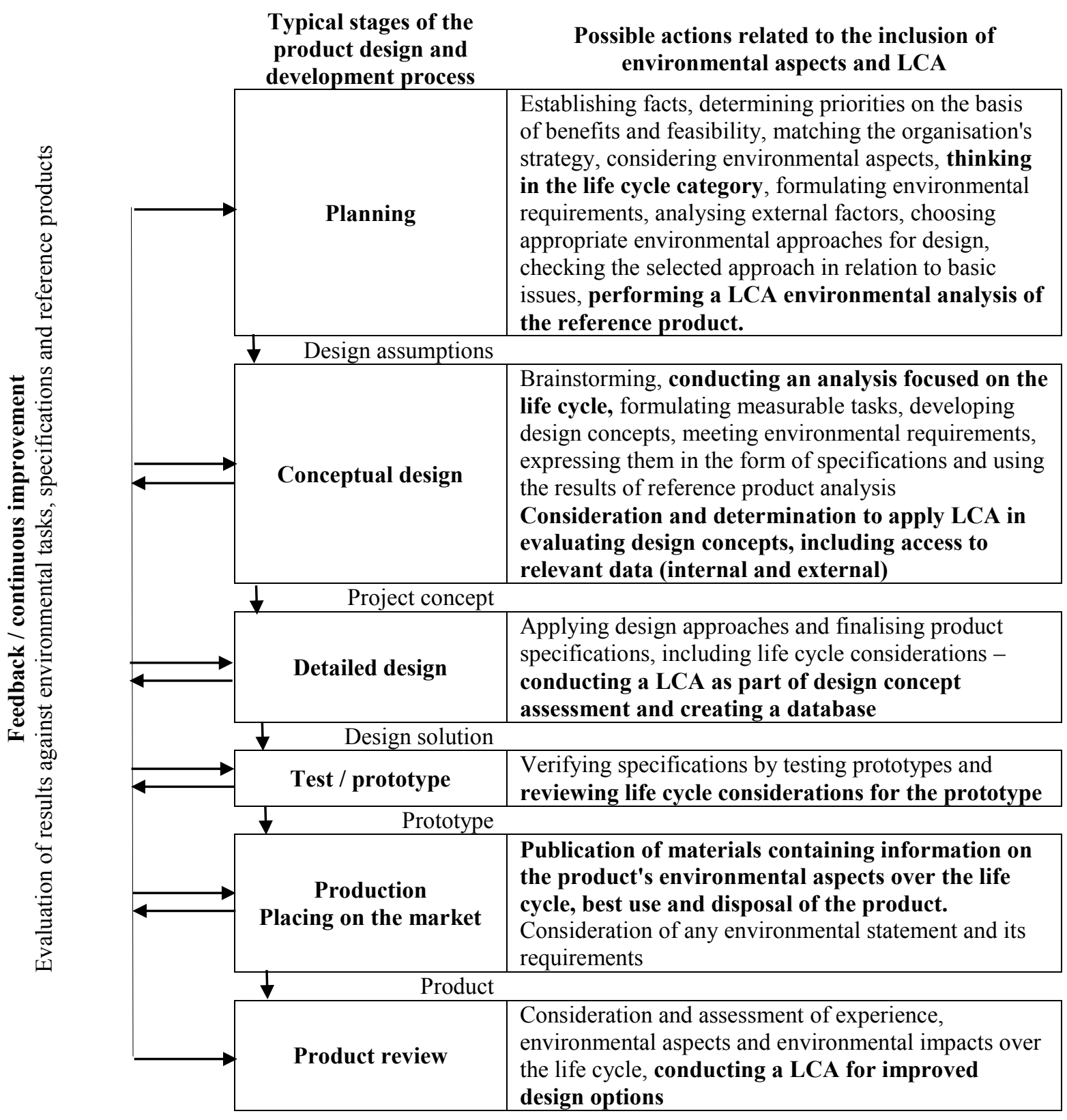

Figure 1. An example of a general model for incorporating environmental and LCA aspects into the product design and development process. Source: own study based on: PKN-ISO/TR 14062:2004 Environmental management - Integrating environmental aspects into product design and development. Polish Committee for Standardisation, Warsaw, p. 21.

At the planning stage, external factors affecting the product are analysed, including environmental requirements, e.g. effective and economical use of resources, protection of human health and the environment in specific areas, reduction of emissions and waste at various stages of the life cycle that are significant for the environment (ISO/TR 14062, 2002). From the beginning, it is therefore possible to include a life cycle perspective. LCA at this stage (in a simplified or detailed version) can be carried out for the reference product. In a situation where the designed product is new to a given organisation, the reference product may, for example, represent the best available BAT technique (design by analogy) or may be based 
on the desired features of a hypothetical product. On the other hand, if an existing product is perfected, it can act as a reference product ('continuous' design) (Kurczewski, and Lewandowska, 2008).

At the conceptual design stage, based on specific product requirements, environmental goals are set for specific environmental aspects. An analysis focused on the life cycle is carried out. Applying the LCA to gather necessary information is also being considered. The result of this stage is the selection of one or more possible concepts that best meets all requirements (ISO/TR 14062, 2002).

Solutions for design specifications are developed for selected design concepts as part of a detailed project. Further development of selected design concepts may require detailed information and data related to the entire product life cycle and possible environmental impacts. Such data can be obtained from external and internal sources (ISO/TR 14062, 2002). Based on them, it is possible to conduct a detailed LCA analysis, which will provide quantitative information on the potential impact of the proposed solutions on the environment (Baran J., 2016).

The LCA analyses can be useful at the stage of research and prototype creation, as well as placing on the market. It is thus possible to verify the assumptions made and to inform subsequent entities in the value chain regarding product handling at the stage of use and management of post-use waste.

After placing on the market, the organisation may conduct a review including market feedback (ISO/TR 14062, 2002), as well as new possible technical and environmental solutions, including eco-innovation.

The eco-design process focuses on specific design approaches for which it is possible to develop quantitative comparative information through the use of LCA (primarily the environmental footprint). As part of circular economy these are (COM/2020/98 final):

- improving product durability, reusability, development and repair, reducing hazardous chemicals in products, increasing their energy efficiency and resource efficiency,

- increasing the content of recycled materials in products while ensuring their efficiency and safety,

- enabling product regeneration and high quality recycling,

- reduction of carbon and environmental footprint,

- limiting one-time use and preventing premature ageing of products,

- using the 'product as a service' model and other models where manufacturers remain the owners of the products or are responsible for their operation throughout the life cycle,

- harnessing the potential of product information digitisation, including solutions such as digital passports, marking and watermarks. 


\subsection{Strategic planning}

Strategic planning is a systematic process through which an organization agrees on-and builds commitment among key stakeholders to - priorities that are essential its mission and are responsive to the environment. Strategic planning guides the acquisition and allocation of resources to achieve these priorities (Allison, and Kaye, 2005). Strategic planning is based on the strategic information system shaped by the enterprise (Dźwigoł, 2011; Lichtarski, 1999; Wolniak, 2020a).

Fast and often unpredictably changing conditions of enterprise functioning imply the necessity of a new, dynamic approach to strategic management, which allows building a strategy based on opportunities and innovations (Dźwigoł, 2011; Rokita, 2006). The existing concept of strategic planning requires supplementation with processes of creating and maintaining a competitive advantage through dynamic vision of strategic management. The new socio-cultural business system is a goal-seeking organisation or part of it and its stakeholders, existing within a larger social network that can be distinguished by common goals, values and culture. These theses form the basis for new methodological systems new strategic management, the so-called mix management (management methods in conditions of environmental instability), including mainly knowledge management methods and organising knowledge management (Dźwigoł, 2011; Wolniak, 2020b).

New ways of observing and analysing markets, other relations with customers, introducing new, innovative products, rational selection and use of resources, as well as the application of processes and management systems that are different than before imply the need to search for new business models (Brzóska, 2009; Jabłoński, and Jabłoński, 2016; Kaźmierczak, and JonekKowalska, 2020), which are part of the overall business strategy. A business model is a tool containing a certain set of elements and relationships between them, in a schematic (more or less detailed) way of presenting a business idea (Brzóska, 2009).

In $\mathrm{CE}$, the business model plays the role of a tool for the operationalisation of closed loop business parameters. It can be understood as 'mapping the structure of relations between factors in a given place, time and business space that guarantees meeting current, internal and external needs of stakeholder groups, which enables the enterprise to achieve current competitive advantage and is a creation of the future platform of enterprise growth and development ensuring business continuity’ (Jabłoński, and Jabłoński, 2016).

Moreno et al. define five circular business model archetypes (Moreno et al., 2016):

- Circular supplies: A business model based on industrial symbiosis in which the residual outputs from one process can be used as feedstock for another process.

- Resource value: A business model based on recovering the resource value of materials and resources to be used in new forms of value.

- Product life extension: Those business models that are based on extending the working life of a product. 
- Extending product value: Those business models based on offering product access and retaining ownership to internalise benefits of circular resource productivity.

- Sharing platforms: Those business models that enable increased utilisation rates of products by making possible shared use/access/ownership.

Business model archetypes reflect the directions of development of business space and thus can be the foundation for building new models, strategies and strategic planning. Choosing the right strategic solutions in circular economy first requires comparing them. This can be done in a comprehensive way by applying the LCA. The life cycle approach leads to an environmental profile of various solutions that are sometimes surprising and often non-intuitive.

M. Lewandowski proposes a circular business model that stands out among a wide variety of approaches in this area by focusing on implementing a new business paradigm within the circular economy, while also taking into account the perspective of a single enterprise, which can be an inspiration in formulating goals and methods of their implementation (Lewandowski, 2016).

The template of the business model defined in this way systematises the areas of activities that should be considered and undertaken as part of the implementation of CE assumptions. The key component of the model is the value proposition, the essence of which is added value as part of the implementation of $\mathrm{CE}$ assumptions. The product in this approach is characterised by an extended period of 'life', e.g. by enabling repair, renovation, redistribution, updating or resale. Assuming that by design, it will be designed so that it can be reused or recycled after use. There are also two unique components - return system and adaptation indicators. The return system means creating a space for the reuse, processing, recycling of products, their components and/or materials, which entails the need to organise a network of links within the return system and reverse logistics. Adaptation indicators are a measure of the effectiveness of actions taken in implementing $\mathrm{CE}$ assumptions, providing feedback to improve approaches and practices (Lewandowski, 2016).

LCA can be widely used as a decision-making tool (Liamsanguan, and Gheewala, 2008; Borghi et al., 2007; Piekarski et al., 2013). In this perspective, LCA helps managers find various strategies for an integrated and sustainable management system in the circular economy. In the area of strategic planning, the LCA study is conducted to assess the environmental impact of strategic scenarios (Rebitzer, and Buxmann, 2005; Poeschl et al., 2012; Piekarski et al., 2013). The LCA can also be used to design the supply chain. Newe et al., (2010) includes LCA indicators in the development of green supply chain projects and their operation (Newe et al., 2010).

The application of optional LCIA elements, i.e. normalisation and weighting, may be key in this case. The application of appropriate weighting indicators for specific value choices may be considered. The normalised and weighted LCA results are the basis for comparing different impact categories and damages within one and many business solutions, assuming the use of unified research assumptions. 


\subsection{Public policy making}

The circular economy has become a strategic goal at EU level (Baran B., 2019). The CE is a special set of activities under public policy, which defines, among others sustainable product policy and waste policy. The LCA is a tool that can realistically support the development of public policy.

There are two main theories of public policy development (Bras-Klapwijk, 1998; Seidel, 2016):

- discourse theory stresses the need for an open and inclusive process in which stakeholders learn about each other's perceptions on the issues, with a focus on communication and understanding,

- rational theory emphasizes quantification and objectivity, with technical information being the key factor in the process.

In the first case, the key function of LCA is to support and stimulate reliable discussion, and life cycle research supports the full and open communication process between stakeholders with different interests and perspectives (Seidel, 2016).

In the second case, LCA can support the process of creating and developing public policy, providing decision makers with relevant comprehensive information (Allen et al., 1995). This rational approach is particularly relevant and useful in technically oriented public policy decisions, such as infrastructure design or technology selection (Seidel, 2016).

The LCA can make a valuable contribution to public policy formulation because it allows decision makers to consider potential unintended environmental consequences that cannot be predicted otherwise (Seidel, 2016). The application of life cycle concepts and tools can also bring together scientific and policy-making communities on the other, as part of an overall effort to strike a balance between economic and environmental criteria, through a more holistic decision-making perspective (Allen et al., 1995; Seidel, 2016). The LCA also has a broader scope than most other tools, and therefore can potentially provide a long-term vision that will help identify opportunities for major improvements (Allen et al., 1995; Seidel, 2016).

It is also worth mentioning Green Public Procurement (GPP), which is an instrument of public policy implementation. The GPP is a powerful tool to stimulate innovation and encourage enterprises to develop new, greener products. The European Commission is trying to fully use this potential through various actions. The Public Procurement Directives allow the contracting authority to include requirements for processes and production methods or provision of services in the technical specifications for supply, service and works contracts (Green Public Procurement).

Many public authorities in Europe have adopted the approach of establishing a policy on green public procurement, or incorporating into a different policy area obligations regarding the granting of green public procurement (Buying Green!, 2016). 
The purchasing power of public authorities accounts for $14 \%$ of EU GDP and can be a strong factor in increasing demand for sustainable products. To exploit this potential, CE will propose minimum mandatory criteria and goals for green public procurement in sectoral legislation, and mandatory reporting will gradually be introduced to monitor the extent of the use of green public procurement (GPP), without introducing unjustified administrative burdens for public purchasers (COM 2020/98 final).

The life cycle assessment of the goods, services or works being the subject matter of the contract may be helpful in developing appropriate process specifications and production methods. It is necessary to use harmonised sets of criteria, which in many countries implementing GPP, rely on LCA data, if available, and on environmental labels and evidence underlying these labels (Buying Green!, 2016).

As part of green public procurement, you can use LCA carried out for a specific contract, as well as ready-made environmental labels, the receipt of which involves the prior carrying out of a LCA and verification of its correctness and reliability by a third party.

It should be emphasised that the use of the life cycle concept for environmental labelling is one of the most important applications of this concept in the public sphere. The main purposes of introducing environmental labels include (Allen et al., 1995):

- stimulating changes in consumer behaviour, which in turn will result in better products being offered in terms of environmental impact,

- accurate, honest and reliable information on the environmental impact of products, which will help consumers make decisions not only based on cost and performance criteria, but also environmental,

- educating consumers about the environmental aspects of products and the impact of their purchasing decisions on reducing environmental impact.

The contracting authority, before commencing the procedure for awarding a public procurement, may conduct a technical dialogue, requesting advice or providing information to the extent necessary to prepare a description of the subject matter of the contract, contract terms of reference (TOR) or determining the terms of the contract (in Polish law: Ustawa $\mathrm{z}$ dnia 29 stycznia 2004 r. Prawo zamówień publicznych). The Contractor, taking part in consultations as part of technical dialogue, can acquire knowledge that helps to better meet the expectations of the contracting authority, and the contracting authority has the opportunity to acquire knowledge in the field of the best and latest technical, organisational and economic solutions, as well as environmental (e.g. through the use of the LCA) confrontation needs with the possibility of their implementation, determining the factors determining the quality and amount of costs.

Special opportunities for conducting innovative green public procurement are associated with the application of Pre-Commercial Procurement (PCP). This procedure is not regulated by the PCP, because its subject matter are services in the field of scientific research and development works as well as the provision of research services that are not paid in full by the 
contracting authority or whose results do not exclusively constitute its property. Completion of the PCP procedure is also the basis for starting the public procurement procedure. The contracting authority prepares the contract terms of reference and all other tender documents based on the chosen solution proposed by the suppliers who have reached the end of the research and development stage (Baran J., 2015). The LCA can also be used in this procedure, especially as it enables the inclusion of scientific research.

\subsection{Marketing}

Empowering consumers and enabling them to save money is a key element of the CE policy framework for sustainable products. To increase consumer participation in the circular economy, work will be undertaken to provide consumers with access to reliable and relevant information on products at the point of sale, including on their service life and the availability of repair services, spare parts and repair instructions. Actions will be taken to increase consumer protection against the use of fake green marketing and premature ageing of products by setting minimum requirements for sustainability labelling / logo and information tools (COM 2020/98 final).

Actions will also be taken to ensure that enterprises justify their claims on environmental performance (product, service) using methods that relate to the environmental footprint of the product and organisation. The European Commission plans to test the inclusion of these methods in the EU Ecolabel and will more systematically include sustainability, ability to recycle and the content of recycled materials in the EU Ecolabel criteria (COM 2020/98 final).

Strengthening the position of consumers in CE implies undertaking new marketing activities, or rather green marketing. Their overarching goal is to identify market conditions for the implementation and improvement of new solutions and the proper interpretation of information that can be obtained from this market.

Among the challenges of green marketing, current in the context of CE, we can distinguish (Lewandowska et al., 2017):

- specific stakeholders appear in green marketing, among which we can distinguish land, animals and plants, and future generations. A characteristic feature of these entities is that they have no real impact on the marketing strategies implemented. The challenge is the perception and communication of this aspect by top management as a value;

- environmental information directed to the customer and/or consumer is often abstract due to the fact that e.g. emissions, energy or water consumption is reduced at a different place and time than the place and time in which the product is used. In addition, the pro-environmental aspects of the product are far from the tangible functional and physical characteristics of the product, and the environmental impact - especially when it is completely and honestly communicated - can be difficult to understand; 
- in many cases, organic products are more expensive, which can be a buying obstacle. The goal of eco-marketing communication should be to justify this and convince the buyer that the product is worth the higher price;

- many actions taken to obtain certificates, labels, and confirmation of undertaken proenvironmental actions require the participation of the so-called third party, i.e. auditor, verifier. It is therefore necessary to obtain support from relevant organisations;

- it can be argued that there are difficulties in perceiving eco-design as a process that generates marketing environmental information that can be reliably passed on to customers in a legible manner.

It seems that the strength of the LCA in marketing is more and more often noticed, because many results are currently published in various reports, including CSR, or even by informing customers about the size of the carbon footprint. This also applies to environmental labels.

But it should also be noted scepticism, both manufacturers, marketers and customers in recognition of the reliability of such information. This is due to the fact that comparing two or more products, so desired by companies and customers (both in $\mathrm{B} 2 \mathrm{~B}$ and $\mathrm{B} 2 \mathrm{C}$ relations), is also extremely difficult to achieve. It requires applying uniform analytical assumptions.

The solution to this problem is the use of LCA for older and newer generation products analysed according to the same assumptions, or the applying of Category Rules as part of an environmental footprint (Lewandowska et al., 2017). It is a solution that also brings a new Action Plan for CE.

The LCA in a more general form can be used for the definition of marketing strategies of the organisation, disseminating the advantages related to the products compared to other existing products (Piekarski et al., 2013).

According to the UNEP/SETAC (Life Cycle Management, 2009) LCA can assist in decision-making related to marketing, for example, for the implementation of an eco-labeling project (Eco labeling), or the environmental statement of the product. This emphasises that LCA allows developing a 'green' marketing strategy (Piekarski et al., 2013). There should be uniform assumptions here.

Thanks to LCA, it is possible to identify opportunities to improve the environmental performance of products at various points in its life cycle (Life Cycle Management, 2009) and thus contribute to the development and implementation of eco-innovation (Zarębska et al., 2019).

The efforts of the European Commission in developing an environmental information format for consumers are also worth noting. The use of an environmental footprint is the basis for obtaining this information.

Information could be presented in many forms, for example (Product Environmental Footprint Information): 
- on a performance scale, where $\mathrm{A}$ is best environmental performance and $\mathrm{E}$ is worst performance,

- as a "traffic light" system, where the average, the better and the worse than average is shown,

- how the product performs respectively to itself some years ago,

- as factsheets that present the most relevant environmental impacts, the performance of the product and tips on how to use them,

- as infographics explaining the environmental features of the product,

- information on websites, online shops or apps.

\section{Conclusion}

Circular economy is based on a system approach in the field of 'closing the loop' in biological cycles (restoring non-toxic materials to the biosphere while restoring natural capital) and technical cycles (reducing dependence on primary materials by restoring products, components and materials to the market in the highest possible quality and as long as possible. This brings new requirements and challenges in terms of reformulating a product offer by manufacturers and considering new possibilities in the field of public policy.

The LCA is a method by which it is possible to comprehensively analyse the product's environmental impact throughout the entire life cycle. Unified methodological assumptions under the environmental footprint (which is a unified version of LCA) create the foundation for a system in which it will be possible to compare products, as well as obtain transparent product information in the case of customers.

The article presents the application of LCA in relation to the circular economy proposal. On the one hand, we have a tool that is becoming the standard in quantifying the impact of the life cycle on the environment. On the other hand, there are challenges that affect public authorities, organisations, manufacturers and customers.

The final conclusions are:

- Sustainable product policy frameworks covering sustainable product design, empowering consumers and public buyers, and a closed loop in production processes, set out in the new Circular Economy Action Plan require precise analytical tools such as LCA.

- The eco-design process implemented in enterprises requires LCA support primarily at the stage of development of selected design concepts. Using detailed LCA can provide quantitative information on the potential environmental impact of the solutions being designed over the life cycle. The use of LCA at the design stage is the most effective 
way to reduce environmental impact, because decisions made at the design stage are responsible for up to $80 \%$ of products' environmental impact throughout the entire life cycle.

- LCA is a decision-making tool that helps managers evaluate various strategies for an integrated and sustainable management system in circular economy. LCA can also be used to design the supply chain. LCIA optional elements such as normalization and weighing are useful in this regard.

- LCA as a tool with a long-term perspective of the analysed aspects has the potential to make a valuable contribution to the formulation of public policy. It allows policy makers to consider potential unintended environmental consequences that cannot be predicted otherwise. LCA supports the full and open communication process between stakeholders with different interests and perspectives. In addition, the assessment of the life cycle of goods, services or works subject to green public procurement can help develop appropriate process specifications and production methods.

- Strengthening the position of consumers in CE implies undertaking new marketing activities, or actually green marketing. Their primary goal is to identify market conditions for the implementation and improvement of new solutions and the proper interpretation of information that can be obtained from this market. LCA in the form of an environmental footprint, as a tool developed by the European Commission, contributes to building the foundations of a system in which marketing information supported by LCA goes to conscious customer.

\section{Acknowledgements}

The article is the result of research carried out at the Department of Economics and Informatics at the Faculty of Organization and Management of the Silesian University of Technology as part of the statutory work entitled "The use of business analytics in the economy, in particular in smart cities and Industry 4.0" marked with the symbol BK-235/ROZ-1/2020 (13/010/BK_20/0042). 


\section{References}

1. Allen, D.T., Consoli, F.J., Davis, F.J., Davis, G.A., Fava, J.A., Warren, J.L. (1995). Public Policy Applications of Life-Cycle Assessments - Proceedings from the Workshop on Application of Life-Cycle Assessment to Public Policy. In: T.D. Allen, F.J. Consoli, G.A. Davis, J.A. Fava and J.L. Warren (Eds.), SETAC Technical Publications Series. August, 1995. ISBN 1-880611-18-X Assessment - Principles and framework, 2006-07-01.

2. Allison, M., Kaye, J. (2005). Strategic planning for nonprofit organizations. A practical guide and workbook. Hoboken, New Jersey: John Wiley \& Sons, Inc.

3. Baran, B. (2019). The Circular Economy in EU Policy as a Response to Contemporary Ecological Challenges. Gospodarka Narodowa, 4(300), pp. 31-51.

4. Baran, J. (2015). Ekoprojektowanie innowacji nabywanych w ramach zielonych zamówień publicznych. In: R. Knosala (Ed.), Innowacje w zarzadzaniu i inżynierii produkcji. T. 1, (pp. 13-25). Opole: Oficyna Wydaw. Polskiego Towarzystwa Zarządzania Produkcją.

5. Baran, J. (2016). Redesign of steam turbine rotor blades and rotor packages Environmental analysis within systematic eco-design approach. Energy Conversion and Management, vol. 116, pp. 18-31.

6. Baran, J. (2017). Designing a circular product in the light of the semantic design areas. In: K.S. Soliman (ed.), Education Excellence and Innovation Management through Vision 2020: From Regional Development Sustainability to Global Economic Growth. Proceedings of the 29th International Business Information Management Association Conference, Vienna, Austria, 3-4 May 2017. International Business Information Management Association, pp. 3276-3291.

7. Baran, J. (2019). Life cycle approach-based methods - overview, applications and implementation barriers. Sil. Univ. Technol. Sci. Pap., Organ. Manage., 136, pp. 9-23.

8. Bhander, G.S., Hauschild, M., McAloone, T. (2003). Implementing Life Cycle Assessment in Product Devleopment. Environmental Progress, 22, pp. 255-267.

9. Borghi, A.D., Binaghi, L., Borghi, M.D., Gallo, M. (2007). The application of the environmental product declaration to waste disposal in a sanitary landfill. The International Journal of Life Cycle Assessment, 12(1), pp. 40-49.

10. Bras-Klapwijk, R.M. (1998). Are life cycle assessments a threat to sound public policy making? Delft University of Technology, Policy and Management, Department of Policy Analysis, The Netherlands. The International Journal of Life Cycle Assessment, 3(6), pp. 333-342. doi:10.1007/BF02979344.

11. Brzóska, J. (2009). Model biznesowy - współczesna forma modelu organizacyjnego zarządzania przedsiębiorstwem. Organ. i Zarz., Nr 2, pp. 5-23.

12. Buying green! (2016). A handbook on green public procurement. Luxembourg: Publications Office of the European Union. 
13. COM (2019) 190 final. Report from the Commission to the European Parliament, the Council, the European Economic and Social Committee and the Committee of the Regions on the implementation of the Circular Economy Action Plan, Brussels, 4.3.2019.

14. COM/2020/98 final. Communication from the Commission to the European Parliament, the Council, the European Economic and Social Committee and the Committee of the Regions. A new Circular Economy Action Plan for a cleaner and more competitive Europe, 11.3.2020.

15. Directive 2009/125/EC of the European Parliament and of the Council of 21 October 2009 establishing a framework for the setting of ecodesign requirements for energy-related products, OJ L 285, 31.10.2009, pp. 10-35.

16. Dźwigoł, H. (2011). Organizacja przedsiębiorcza w warunkach XXI wieku. Zesz. Nauk. P.Śl., Org. Zarz., z. 56, pp. 41-58.

17. European Platform on Life Cycle Assessment. European Commission Environment. Accessed at https://eplca.jrc.ec.europa.eu/, Jun 6, 2020.

18. Green Public Procurement, Accessed at: https://ec.europa.eu/environment/gpp/ index_en.htm, Jun 5, 2020.

19. ISO 14040 (2006). Environmental management - Life cycle assessment - Principles and framework.

20. ISO 14044 (2006). Environmental management - Life cycle assessment - Requirements and guidelines.

21. ISO/TR 14062 (2002). Environmental management - Integrating environmental aspects into product design and development.

22. Jabloński, A., and Jabloński, M. (2016). Research on business models in their life cycle. Sustainability, 8, 430.

23. Kaźmierczak, J., and Jonek-Kowalska, I. (2020). Environmental data and information for the needs of managing smart cities. In: International Conference on Geolinks, Plovdiv, Bulgaria, 23-25 March 2020. Conference proceedings. Book 2. Vol. 2, Ecology and environmental studies. Environmental economics. Green buildings technology and materials. Green design and sustainable architecture. Slovak Academy of Sciences, Czech Academy of Sciences, National Academy of Sciences of Ukraine, Bulgarian Academy of Sciences, Polish Academy of Sciences, Academy of Sciences of Hungary, Serbian Academy of Sciences, Turkish Academy of Sciences, Academy of Sciences of Moldovia, Islamic World Academy of Sciences, Latvia Academy of Sciences. Sofia: Saima Consult Ltd., pp. 25-34.

24. Kurczewski, P., and Lewandowska, A. (Eds.) (2008). Zasady prośrodowiskowego projektowania obiektów technicznych dla potrzeb zarządzania ich cyklem życia. Poznań: Wyd. KMB DRUK.

25. Lewandowska, A., Witczak, J., Kurczewski, P. (2017). Green marketing today - a mix of trust, consumer participation and life cycle thinking. Management, Vol. 21, No. 2, pp. 28-48. 
26. Lewandowski, M. (2016), Designing the Business Models for Circular Economy - Towards the Conceptual Framework. Sustainability, 8, 43.

27. Liamsanguan, C., Gheewala, S.H. (2008). LCA: A decision support tool for environmental assessment of MSW management systems. Journal of Environmental Management, 87(1), pp. 132-138.

28. Lichtarski, J. (Ed.) (1999). Podstawy nauki o przedsiębiorstwie. Wrocław: Akademia Ekonomiczna.

29. Life Cycle Management: How business uses it to decrease footprint, create opportunities and make value chains more sustainable. UNEP/SETAC, 2009.

30. Lockrey, S. (2015). A review of life cycle based ecological marketing strategy for new product development in the organizational environment. Journal of Cleaner Production, Vol. 95, pp. 1-15.

31. Moreno, M., De los Rios, C., Rowe, Z., and Charnley, F. (2016). A conceptual Framework for Circular Design. Sustainability, 8, 937.

32. Newe, E.S., Adhitya, A., Halim, I., Srinivasan, R. (2010). Green Supply Chain Design and Operation by Integrating LCA and Dynamic Simulation. Computer Aided Chemical Engineering, 28(1), pp. 109-114.

33. Olkiewicz, M., Wolniak, R., Skotnicka-Zasadzień, B. (2019). Implementation of ISO 14001 standard in the European Union countries. Rocz. Ochr. Środ., t. 21, $n r$ 2, pp. 868-880.

34. Piekarski, C.M., Mendes da Luz, L., Zocche, L., de Francisco A.C. (2013). Life Cycle Assessment as Entrepreneurial Tool for Business Management and Green Innovations. J. Technol. Manag. Innov., Vol. 8, Iss. 1, pp. 44-53.

35. Poeschl, M., Ward, S., Owende, P. (2012). Environmental impacts of biogas deployment e Part II: life cycle assessment of multiple production and utilization pathways. Journal of Cleaner Production, 24(5), pp. 184-201.

36. Poudelet, V., Chayer, J.A., Margni, M., Pellerin, R., Samson, R. (2012). A process-based approach to operationalize life cycle assessment through the development of an eco-design decision-support system. Journal of Cleaner Production, 33, pp. 192-201.

37. Product Environmental Footprint information Accessed at: https://ec.europa.eu/ environment/eussd/smgp/communication/product_information.htm, Jun 6, 2020.

38. Rebitzer, G., Buxmann, K. (2005). The role and implementation of LCA within life cycle management at Alcan. Journal of Cleaner Production, 23(13), pp. 1327-1335.

39. Results and deliverables of the Environmental Footprint pilot phase. Accessed at: https://ec.europa.eu/environment/eussd/smgp/PEFCR_OEFSR_en.htm, Jun 2, 2020.

40. Rokita, J. (2006). Dylematy stojące przed zarządzaniem strategicznym. In: J. Rokita, W. Grudzewski (Eds.), Strategie korporacji działajacych $w$ skali ponadnarodowej (pp. 93-103). Katowice: GWSH.

41. Seidel, Ch. (2016). The application of life cycle assessment to public policy development. International Journal of Life Cycle Assessment, 21, pp. 337-348. 
42. Ustawa z dnia 29 stycznia 2004 r. Prawo zamówień publicznych. Dz.U. 2004 Nr 19, poz. 177.

43. Wolniak, R. (2020a). The methods of measurement of enterprise internalization. Sil. Univ. Technol. Sci. Pap., Organ. Manage., 144, pp. 627-637.

44. Wolniak, R. (2020b). Quantitative relations between the implementation of industry management systems in European Union countries. Sil. Univ. Technol. Sci. Pap., Organ. Manage., 142, pp. 33-44.

45. Zampori, L., and Pant, R. (2019). Suggestions for updating the Product Environmental Footprint (PEF) method, EUR 29682 EN, Publications Office of the European Union, Luxembourg, ISBN 978-92-76- 00654-1, doi:10.2760/424613, JRC115959.

46. Zarębska, J., Żabińska, I., Zarębski, A. (2019). Eco-innovations in Poland - the extent of changes, development and barriers. Sil. Univ. Technol. Sci. Pap., Organ. Manage., 135, pp. 245-256. 